to increase. Enthoven, evidently an optimist, believes that the pace of growth will now be slower, as government regulation and market forces limit some of the component costs - physicians' salaries and/or the substitution of paramedics for physicians, for example. But he acknowledges that the United States has not solved the problem of the indigent (many of the 35 million people without medical insurance) and that the future is clouded because there is no knowing whether the technology of applied biology (called medicine) will keep people healthy for longer or instead create more expensive ways of staying alive.

That is the uncertainty the British National Health Service was meant to resolve, and which seems to have been overlooked in the run-up to last week's British general election. Mr Aneurin Bevan. the Labour politician who created the health service in 1947, made it a pillar of his case that no-charge access for all would reduce even the then meagre need to spend on medicine; he was right in guessing that infections would quickly disappear from among the causes of death, but he reckoned without coronary by-pass operations and the like. Enthoven might have strengthened his case by guessing that some of these may also disappear when, for example, biotechnologists have found the best ways of delivering declotting enzymes to blood-clots. Yet there are likely always to be as many expensive life-preserving innovations as radically cheaper versions of existing treatments. Enthoven's economic optimism is no more compelling than Bevan's more qualitative opinion about the long-term economic benefits of preventive medicine.

It was inevitable that the conundrum should have featured in the British general election, but its appearance was curiously muffled. The Labour opposition party (as it remains) complained repeatedly about the shortage of resources in the National Health Service. The government's standard reply was : at resources have not been cut, but rather increased. Both disputants are correct. Although, at one stage, the prime minister, Mrs Margaret Thatcher, was reminding radio listeners that her government has increased the annual budget of the National Health Service from $£ 9,000$ million in 1979 to $£ 21,000$ million now, inflation has eaten away at the figures. In real terms, spending has increased by 26 per cent over the past 14 years, while much of the extra has been necessary to maintain recruitment of nurses and other paramedical professionals. Meanwhile, with private spending on health care merely 5 per cent of the total, Britain is spending both a smaller proportion of national income (just under 7 per cent) and a smaller absolute sum each year (an average of $£ 400$ per head of population) on health care than are countries such as the United States, West Germany and those of Scandinavia.

In such circumstances, it is inevitable that those who can afford it will purchase medical care privately, usually through insurance schemes. Thatcher ran into trouble from her opponents during the election by allowing that she does just that. The counter-complaint, that access to medical services should be determined exclusively by need, and not by a person's ability to pay, is tenable only when the resources available are at least enough to meet all needs - which in Britain at present would probably mean an extra $£ 10,000$ million. Nobody, during the election, was talking that big.

So does that mean that the principles of the British National Health Service must be abandoned? Even those who voted last week for Thatcher have made plain their attachment to the National Health Service, whatever its inadequacies, and for good reason. Over 40 years, "socialized medicine" has contributed powerfully to the civility of British life by ensuring that children, the elderly and the chronically sick are well catered for, and that the poor do not need to pay. It is high time that countries such as the United States more energetically followed suit. But the device by which people in jobs purchase health care separately through insurance schemes, far from being subversive of the principles of the health services, is a means by which extra resources can in present political circumstances be found.
The logic of Thatcher's personal position requires that she and her government should do more to encourage the development of private medical insurance in Britain. (Payments are not taxexempt in Rritain, hut were specifically excluded from the list of tax deductions snatched away by last year's US Tax Reform Act. ) The end result might not be very different from that in the United States and West Germany, with the reservation that those in need continue to receive the treatment they need.

The health economists contributing to this week's symposium would approve. In strictly economic terms, the need in Britain and similar places is merely to recruit extra resources for the health services; whether they come from taxation or from private contrihutions to insurance schemes is irrelevant to a first approximation (but, to a second approximation, may bear on the efficiency with which health services are managed and on the more contentious question, in Britain, of whether public and private hospitals should be physically separate). But, in the long run, there will be no escape from the dilemma that the cost of innovations that prolong life will always increase so as to exceed what the richest countries can afford; the marginal cost of increasing people's expectation of life must be an increasing function which, at some point, may even be infinite.

Is one resolution of this difficulty to be found in the contribution to this symposium from Professor Alan Williams, of the University of York, who argues for allowing patients threatened with death to make intelligent choices between alternative treatments on the basis of objective studies of the effect of their outcome on the quality and additional extent of life that people may then expect? That would be a great simplification of present dilemmas. If people's rational choices of alternative treatments had the effect of containing the marginal cost of longevity, the administrators would be happy. Such a development would also be consonant with the modern rediscovery of the inevitability of death. The snags are that many physicians would regard such considerations as an extra and even intolerable responsibility which would, more generally, raise ethical questions such as those arising in the consideration of euthanasia. Williams is nevertheless right to ask that the questions should be faced, preferably on the basis of data yet to be gathered about the quality of life of people surviving traumatic medical treatments. The trouble, even if the data were available and used, is that the marginal cost of treatment for all woudl still be greater than societies believe they can afford. What, people must one day ask, is to happen then?

\section{Buying nuclear power}

The new British government should think hard about its plan to denationalize electricity.

$\mathrm{M}_{\mathrm{R}}$ Cecil Parkinson, energy minister in the new British government (see p. 543), is right to say that there is some thinking to do before the nationalized British electricity utilities can be sold. That is to put it mildly. Over more than half a century, Britain's pride has been its investment in a national grid, a network of high-voltage transmission lines for distributing electric power over a small patch on the surface of the Earth whose economic henefit has been that consumers could gather electrons economically from power stations sited more or less anywhere in the country. Integration has been the name of the game so far, but selling off an integrated network and its attendant power stations to a private monopoly is an invitation to abuse. Logically, the new private company should own the grid and should buy the electricity it distributes (on appropriately long-term contracts) from whoever is willing to take the risk of building power stations (some of which will be nuclear). That way, consumers would be protected. while plant manufacturers would have an incentive to compete with each other. Otherwise, it is the managers of the present system who will benefit. Which way will a market-oriented government decide? 